\title{
Working Time and Family Responsibilities in Spanish Labour Law: an Overview on the Current Situation
}

\author{
Ma del Carmen Pardo García \\ Graduate in Law and Economics \\ Universidad Carlos III de Madrid (2014)
}

Recibido: 03.05.2016

Aceptado: 14.06 .2016

DOI: http://dx.doi.org/10.20318/sllerj.2016.3310

\begin{abstract}
The Spanish legal foundation on working time does not create a favourable atmosphere for employees to reconcile their work and family responsibilities. This study outlines the institutional figures that permit Spanish employees to reduce or redistribute their working hours; in addition to illustrating some of the differences with other European workers. In Spain, the lack of social awareness regarding reconciliation of labour and family life is apparent in that its regulation does not emerge from an initiative of the Spanish parliament, but rather, results from the transposition of guidelines established by the international and European communities. Therefore, Spanish employees having family responsibilities find it harder to achieve a balance between work and family as compared to their colleagues in Denmark, the Netherlands, Sweden or Germany. Furthermore, Spanish data from 2005 to 2014 has been analysed in order to determine if a change in trend has occurred with regards to reconciliation or if, on the contrary, we are witnessing the perpetuation of traditional men and women roles.
\end{abstract}

Keywords: reconciliation, part-time work, reduction of working hours, and data.

\section{Introduction}

Work and time are an inescapable combination, inherent to all mankind. From a worker's point of view the importance of time management results from its impact on personal, family and leisure time. From a business perspective however, it is a question of maximising productivity. For both parties, worker security and welfare is the common interest with regards to time management in the workplace.

The personal employee circumstances have played an essential role in the regulation of working time, as seen throughout the history of labour law. The worker's movement initiated as a means of advocating a limitation of working hours until laws were eventually passed to limit its maximum duration. In Spain, since 1983 the maximum duration of working hours has been "forty hours a week of effective work as a total yearly average" (art. 34.1 of Royal Legislative Decree 1/1995, of 24 March revising the text of the Workers' Statute Law, hereinafter referred to as WS) in comparison to the 45 hour a week that was established in 1980.

However, over recent years numerous debates have arisen regarding the possibility of making working hours more flexible. This is evident with the various legislative reforms that are reshaping the WS, and which have been increasing the employer's prerogatives by addressing the "when" question in regards to working hours.

The first measure to promote the flexibility of working hours took place in 1994 through the introduction of Act 10/1994, 19 May, regarding urgent measures to promote employment. This act intro- 
duced the possibility of distributing working hours unevenly throughout the day by means of a collective negotiation agreement. The reform introduced in $2012^{1}$ has further increased the employer's prerogatives by enabling $10 \%$ of the working hours to be unevenly distributed throughout the year. Since then, the schedule of the working hours is no longer an essential element of the employment contract ${ }^{2}$.

Another social demand which has gained strength over recent years, particularly since the female's incorporation within the labour market, is the right to reconcile family and working life.

This fundamental right has been undermined by the fact that it can only be obtained through a collective negotiation. Despite the duty of collective negotiation to adopt a strategy that favours the conciliation of family and working life, current collective negotiation agreements tend to be quite broad in their descriptions of the distribution of working hours. This leads not only to employee insecurity, but it also hinders the development of the right to conciliate work and family life.

The legal limitation of the maximum duration of working hours marked a milestone in the history of labour legislation; however, the incorporation of women into the labour market has created a social and economic transformation that has not currently had a sufficient impact on Spanish labour laws. One cannot currently speak of a truly equal distribution of opportunities between men and women in the labour market.

An effective conciliation between family and working life, in terms of equality, demands a radical change in the organisation of labour, specifically, in terms of working schedules. Changes should be implemented in the productive system and in the corporate organisations in order to achieve a balance between work and family.

The multiple labour reforms that have been implemented over the past decade have focused primarily on labour flexibility in the sense of promoting the power of collective negotiation, to the point of legally supporting the de-regulation of the labour market. But what about the employee's right to reconcile family and working life?

The flexibility of the working hours, which is understood as the mechanism by which corporate necessities are adapted to employee needs, should promote the conciliation of work and family life, not solely for the security and health of the workforce, but also for its repercussions on general interests.

The purpose of this paper is to study Spanish situation regarding employees and family responsibilities and to identify the main differences with that of Dutch, German and Scandinavian workers sharing similar situations. Over the past two years, as a result of the economic crisis, Spain has been forced to make major reforms in various fields, with the labour market being one of the most important. In fact, the latest labour reform of 2012 went hand-in hand with various Acts designed to "improve"/ amend certain aspects of this market.

The balance between work and life has been comprehensively ignored by Spanish legislators recently, and the few reforms that have been adopted are a direct result of European directives. This situation is especially detrimental to female workers, who compared to Scandinavian workers, are not provided with the necessary support by their companies. Employees in Spain have difficulties to access public childcare service as well as to adjust their working hours in order to meet their family necessities. An examination of the different institutional figures that allow workers to adapt their work hours to family needs illustrates the Spanish situation in comparison to that of Scandinavian or Dutch workers. Furthermore, data from the Spanish Statistical Office has been used to determine whether, currently, traditional male-female roles have changed within the labour market.

This study aims to provide a reflection of the Spanish public policies adopted in regards to reconciliation and the situation of European female workers. We proceed as follows: (i) first, we consider the legal basis for work and family reconciliation in Spain; (ii) then we present a review of the different institutional figures that allow employees to reduce or redistribute their working hours, highlighting some differences between Spanish employees and the situation of other European workers; (iii) and finally, we analyse Spanish part-time work data.

\footnotetext{
${ }^{1}$ Act 3/2012, 6 July, on the urgent measures to reform the labour market.

${ }^{2}$ Ballester Pastor, M.A. (2013). "La flexibilidad en la gestión del tiempo de trabajo: jornada y distribución del tiempo de trabajo", Revista de Derecho Social, no. 62, pp. 53-92.
} 


\section{Legal Basis for Work and Family Reconciliation.}

In Spain, normative foundations for the regulation of reconciling work and family life appear in the Constitution, however, it was not until 1999 that Royal Legislative Decree 39/1999, of 5 November, on employee reconciliation of work and family life (hereinafter, Reconciliation Law) was issued, being the first law having the main objective of reconciliation in terms of equality. It is also the only specific law on reconciliation that has been enacted in recent Spanish history.

Nevertheless, this law was not the result of an initiative of the Spanish parliament, but rather, was the result of a transposition of guidelines established by international and European communities to the Spanish legal framework. Specifically, it results from the European Union Directive 92/85/EC, of 19 October 1992, on the introduction of measures to encourage improvements in the security and health at work of pregnant workers and workers who have recently given birth or are breastfeeding (hereinafter referred to as maternity leave) and the Council Directive 96/34/EC of 3 June 1996, on the framework agreement on parental leave concluded by UNICE, CEEP and the ETUC (hereinafter, the directive on parental leave).

Since 1999, new laws have been approved which have half-heartedly introduced political reforms to achieve an equal distribution of opportunities between men and women; Spanish legislation appears to be largely dependent on the European Union. Therefore, European legislation is the main engine of the political reforms that strive to reach a balance between work and life in terms of equality.

\section{A. European Union Legislation}

The design of the Maternity Leave Directive is exclusively aimed towards women and is coherent with its creation in order to protect women during pregnancy and lactation. In addition, this legislation may be considered a conciliation rule, given that it recognizes the right to be absent from work in order to care for new-borns and because its duration exceeds the maximum time required for the physical recuperation of the woman after childbirth. ${ }^{3}$ This directive has been recently modified by Directive 2007/30/EC of de European Parliament and of the Council of 20 June 2007.

The Parental Leave Directive has been approved by means of a framework agreement on parental permission, resulting from the commitment of the UNICE, the CEEP and the UTEC to establish dispositions on parental leave and absence from work due to greater causes, with the objective of enabling the reconciliation of work and family life and to promote equal opportunities between men and women.

This Directive on parental leave was repealed by Directive 2010/18/EU of 8 March 2010, implementing the revised Framework Agreement on parental leave. This new directive recognizes the right to a minimum of four months of parental leave which can be enjoyed either on a full time or part time basis. In the Spanish legal system, full-time parental leave is known as leave of absence to care for children or family or permission for the birth of children, while part-time parental leave refers to a reduction in working hours or the permission for lactation.

The novelty of this new directive on parental leave (Directive 2010/18/EU) is its reference to the distribution of family responsibilities, as it establishes parental leave as being non-transferable, for at least one of the four minimum months of its duration ${ }^{4}$. This directive has yet to be transposed to the Spanish framework.

Directive 2002/73/EC, amending Council Directive 76/207/EEC on the implementation of the principle of equal treatment for men and women as regards access to employment, vocational train-

\footnotetext{
${ }^{3}$ Ballester Pastor, María Amparo (2010). “Conciliación laboral y familiar en la Unión Europea: rémoras, avances y nuevas líneas de tendencia en el ámbito de la corresponsabilidad”, Revista de Derecho Social, no. 51, pp. 39-42.

4 "The leave shall be granted for at least a period of four months and, to promote equal opportunities and equal treatment between men and women, should, in principle, be provided on a non-transferable basis. To encourage a more equal take-up of leave by both parents, at least one of the four months shall be provided on a non-transferable basis. The modalities of application of the non-transferable period shall be set down at national level through legislation and/or collective agreements taking into account existing leave arrangements in the Member States." (Clause 2.2 of Directive 2010/18/EU).
} 
ing and promotion, and working conditions (hereinafter, Directive 2002/73/EC) aims to encourage the adoption of measures to combat all sorts of gender-based discrimination by employers and those responsible for vocational training.

Finally, Directive 2004/113/EC, implementing the principle of equal treatment between men and women in access to and supply of goods and services (Directive 2004/113/EC), aims to safeguard the fundamental principle of equality between men and women, declared in the EU's principal regulatory texts (arts. 21 and 23 of the Charter of Fundamental Rights of the EU and art. 2 of the Founding Treaty of the European Community), in the field of access to and supply of goods and services, as it is a field where gender discrimination is quite common.

\section{B. Domestic legislation}

The legal basis for the regulation of work and family conciliation may be found in the Spanish Constitution, specifically in articles 9, 14, 35 and 39 (hereinafter referred to as CE). Article $14 \mathrm{CE}$ recognizes the fundamental right to equality, prohibiting gender discrimination. In both article 9.3 and $35 \mathrm{CE}$ (although mainly in the latter) equality in terms of ability to work is recognized. In other words, the CE establishes the criterion of equality of opportunities between men and women ${ }^{5}$. Finally, the protection of the family by the authorities is guaranteed by constitutional mandate, as seen in articles 39.1 and $92 \mathrm{CE}$.

Leaving aside the constitutional realm, we shall now discuss some of the innovations introduced not only by the Reconciliation Law but also by other regulatory texts, whose aim is different from worklife balance.

Law 39/1999, of 5 November, reconciliation of work and family life (Reconciliation Law), has extended the right to reduce working hours and the right to extended leave of absence for employees who must care for family members, who due to age or disease, are unable to provide for themselves and cannot perform remunerated work, although only up to the second degree of consanguinity. Furthermore, the law includes individuals suffering from visual and hearing impairment to the already existing, physically or mentally handicapped, so that employees of these workers may have the right to a reduction of working hours.

The Reconciliation Law not only provides men with access to the care of their child as of the moment of his/her birth or incorporation into the family, it also offers women the option of allowing the father to enjoy up to a maximum of ten of the sixteen legally recognized weeks of maternity leave, while also permitting both parents to simultaneously enjoy this leave. ${ }^{6}$

Leave for adoption, permanent fostering and pre-adoptive children under the age of six no longer depend upon the age of the minor in order to determine who may enjoy this right. Furthermore, no dismissal may be motivated by pregnancy, the application or enjoyment of maternity/paternity leave or family care, unless it may be proven to originate from causes other than those mentioned above and that are unrelated to discrimination. Finally, illnesses resulting from pregnancy, childbirth and breastfeeding are included as assumptions which may not be computed as labour absenteeism, and therefore they may not be a cause of contract dismissal.

Act 12/2001 of 9 July, on urgent measures to reform the labour market in order to increase employment and improve its quality (Act 12/2001), following the line established by the Reconciliation Law, has extended regulations on maternity/paternity leave in the case of premature children birth or a mothers' hospitalization needs after childbirth. In fact, this Act enables the father/mother to leave work for one hour or even entitles them to reduce their working hours up to a maximum of two hours, with a proportional salary decrease, while the new-born remains hospitalized. On the other hand, the Act exempts employers from receiving the contribution on behalf of employees, replacing them with maternity/paternity leave.

\footnotetext{
${ }^{5}$ Lorenzo Rodríguez-Armas, Magdalena (2004). "La conciliación de la vida familiar y laboral en serio: apuntes constitucionales para una conciliación acorde con la igualdad y el principio de no discriminación por razón de sexo", Anuario Jurídico y Económico Escurialense, XXXVII, p. 86.

${ }^{6}$ Exposición de motivos de la Ley 39/1999, de 5 de noviembre, de conciliación de la vida familiar y laboral.
} 
Act 39/2006, of 14 December, on promotion of personal autonomy and care for individuals in situations of dependency (Act of dependence), recognizes the right of dependents to be served by public services or concerted care facilities or, in the lack of the same, to receive benefits according to their degree of dependence ${ }^{7}$.

Organic Act 3/2007, of 22 March, on the effective equality of women and men (hereinafter, LOI), is the result of the transposition of two European directives on equality: Directive 2002/73/EC, and Directive 2004/113/EC, into Spanish law.

To promote the reconciliation of work and family life, the LOI regulates paternity leave, whose duration is of thirteen days, extendable in the event of multiple births by two additional days for each child, as of the second child. It also introduces improvements in maternity leave, extending its duration to two weeks in cases of children with disabilities.

As for the reduction of working hours due to legal guardianship, the LOI extends the maximum age of the child from six to eight years old. It also reduces the minimum limit for reducing working hours to one-eighth.

In regards to unpaid leave, its minimum duration has been reduced to four months, while the maximum duration of extended leave of absence for family care was increased to two years. In addition, it is expected that in the future, both extended leaves of absence for legal guardians and family care may be enjoyed in instalments ${ }^{8}$.

The labour reforms carried out over recent years have also dedicated part of their articles to the introduction of certain improvements in the field of conciliation, although they occupy a secondary role. The improvements introduced by Act 3/2010, of 6 July, on urgent measures to reform the labour market (law 3/2012) and by the recent Royal Decree-Law 16/2013, of 20 December, on measures to promote stable recruitment and improve the employability of workers (RD-law 16/2013) are analysed below, in regards to the legal figures being studied.

\section{Institutional figures permitting employees to reduce or redistribute their work hours. Differences with other European countries}

The Spanish legal system has been attempting to respond to worker demands concerning working hours and the work-life balance. Work flexibility may be the answer; however, it does not respond to the goal of increasing worker productivity and reducing working hours, partly because a cultural change amongst employers is necessary in order to achieve this goal.

In fact, the enhancement of collective negotiation as a mechanism to establish appropriate working hours that are compatible with both employer productivity and employee needs, has resulted unproductive and even detrimental to workers.

General legal foundations on working time do not make it possible for employees to satisfactorily balance work and family life. This leads workers to resort to different institutional figures, permitting them to reduce or redistribute their work hours.

\section{A. Reduction of working hours for legal guardianship or for care of family members (Art. 37.5 of the Workers' Statute)}

The reduction of working hours for legal guardianship or care of family members differs from the so called "special working days" which are characterized by extending or reducing working hours and their distribution due to the specific nature of the very work. This is the case for full-time employees exposed to environmental risks.

\footnotetext{
${ }^{7}$ Martín-Llaguno, Marta and Cristina Guirao-Mirón (2013). "El marco jurídico de la conciliación. Revisión de las políticas de conciliación en España desde 1999 hasta 2009”, Portularia, Vol. XIII, no. 1, p. 4.

${ }^{8}$ The Explanatory Memorandum of the LOI.
} 
The reduction of working hours for legal guardianship constitutes one of the cases in which the right to reconcile the labour and family life is achieved. Therefore, it is necessary to begin by introducing the origins of this legal figure which is currently regulated in article 37.5 of the WS.

Reduced working hours in order to care of family members (minors, the disabled or those who are unable to be self-dependant) was one of the novelties introduced by the Reconciliation Law and which gave rise to the modification of article 37.5 WS. Nonetheless, this right to reduced working hours for the guardianship or care of the disabled was initially regulated in article 25.6 of the Employment Relations Act of 1976', (in Spanish "Ley de Relaciones Laborales de 1976”).

Article 37.5 ET drafts responses to changes introduced by Act $3 / 2012^{10}$. The first paragraph has been rewritten, with its most noteworthy modification being the limit of the reduction of working hours, which has decreased from one-third to one-eighth. In addition, the introduction of the word "daily" should be highlighted. Although this last change appears to be insignificant, it means that the reduction of working hours due to guardianship must be directly applied during the daily hours in which the service is made. Thus, the doctrinal and jurisprudential debate regarding the possibility of accumulating working days, by using the weekly or monthly calculation has ended.

The introduction of the word "daily" has led to the limitation of working flexibility, which only benefits employers. The employee may only decide the time of entry and exit ${ }^{l l}$.

According to article $37.5 \mathrm{WS}$, employees who meet at least one of the following conditions may reduce their daily working hours between one-eighth and one-half, with proportionate salary reduction.

1. Employees who for reasons of guardianship, are responsible for children under the age of 12 (since the last modification introduced by Act 16/2013 (Royal Legislation Decree 16/2013).

2. Employees who for reasons of guardianship are responsible for a disabled individual.

3. Employees obliged to care for family members who are unable to care for themselves, but only up to a second degree of consanguinity or affinity.

Furthermore, the employee parent or adopter would be able to reduce at least half of his working hours, with a proportionate salary reduction, in order to care for the minor under his responsibility if said minor suffers from cancer or other major illness or if he/she requires extended hospitalization or prolonged and continued care until reaching the age of 18 . However, the Public Health Service must determine whether or not the minor requires prolonged and continued. The conditions and cases in which a reduction of working hours could be recognized are established in the collective negotiation. For example, a collective negotiation agreement from the Asegurador Reale group establishes the possibility of accumulating a reduction in overall working hours, taking into consideration the necessities of the department (BOE 112 10/05/2013 Ministry of Employment and Social Security).

Recently, the minor's age was increased to 12 , given response to claims of different groups. Until the age of 12, minors need attention their legal guardians since they cannot manage their daily activities such as going to school alone, staying at home alone or using public transport on their own ${ }^{12}$.

This age change brings the Workers' Statute in line with the Basic Public Workers' Statute (Act 7/2007, 12 April).

As for the right to reduce working hours for the care of family members, although the Workers' Statute does not mention it, the right may also be applied between spouses since the Spanish Civil Code

\footnotetext{
9 "El trabajador que tenga a su cuidado directo algún menor de seis años o a un minusválido físico o psíquico, y siempre que no desempeñe otra actividad retribuida, tendrá derecho a una reducción de la jornada de trabajo, de al menos un tercio de sus duración, con la disminución proporcional del salario correspondiente." (art. 25. 6 of Ley 16/1976, de 8 de abril, de Relaciones Laborales).

${ }^{10}$ Regardless the recent change introduced by the Royal Legislation Decree $16 / 2013$, that increased the minor maximum age on behalf of whom the employee could reduce his/her working hours, with a proportional salary decrease.

${ }^{11}$ Herraiz Martín, Ma Sol (2012). "La conciliación de la vida laboral y familiar en la Ley 3/2012: Luces y sombras", in La Regulación del Mercado Laboral: Un análisis de la Ley 3/2012 y de los aspectos laborales del Real Decreto-Ley 20/2012, (Directors: Mercader Uguina, Jesús and Ignacio García-Perrote Escartín), Lex Nova, Valladolid, p. 329.

12 Jover Ramírez, CARmen (2013). "La difícil supervivencia de la conciliación entre la vida laboral y familiar en tiempos de crisis y reforma”, Revista Doctrinal Aranzadi Social, no. 4/2013 parte Doctrina, pp. 5-6.
} 
regulates the obligation of mutual assistance and aid (art. 68). This possibility has been considered by collective negotiation ${ }^{13}$.

It is important to stress that collective negotiation agreements do not give fair treatment to all individuals that give employees the right to reduce their working hours. Whereas these agreements tend to enhance legal provisions regarding childcare, usually by increasing the age of the minor, when it comes to disabled family members or members who, due to their age, cannot manage on their own, collective negotiation agreements simply reproduce that which has been declared by the law. For example, the collective negotiation agreement of Zurich Insurance PLC, Spanish branch (BOE 129 12/09/2013, Ministry of Employment and Social Security) or the collective negotiation agreement of Telefónica Soluciones de Informática y Comunicaciones de España S.A.U (BOE 146 19/06/2012, Ministry of Employment and Social Security).

On the other hand, the expression "manage by themselves", used in the Workers' Statute to define the individual conditions under which employees have the right to reduce their working hours, is applied by Spanish Courts in a restrictive way, making it difficult for employees to exercise their legal rights ${ }^{14}$.

Act 3/2012 has enhanced the role of collective negotiation which has become the mechanism to establish a timetable of organizational requirements in order to reduce working hours. Nonetheless, employees maintain the right to choose the period and schedule in which they wish to work. Regarding this issue, PhD Carmen Jover proposes that, in order to comply with the legislator's intention to combine both employer and employee needs, an open clause should be included, giving priority to the employee preference for timetable organization if no damage is found to result for the company's productivity and the organization ${ }^{15}$.

Ultimately, Act 3/2012 has placed work and family reconciliation in a secondary position, giving power to collective negotiation and leaving employees unprotected with regards to this matter.

An alternative to reducing working hours is boosting public childcare, as is done in other European countries such as Denmark, Finland, Sweden and France. In fact, "a legal right to childcare place exists [...]" in the majority of these countries. "In Denmark, every child has a right to a childcare place from the age of 26 weeks. This is followed by Finland where children have the right to a childcare place from ten months and Sweden where working and studying parents have the right to a childcare place from their child's first birthday. Parents in Germany, Great Britain and France have the right to a childcare place for their children from the age of three years." 16

In addition to the provision of childcare places, the governments of these countries have adopted childcare financing policies in order to ensure the reconciliation of work and family for workers, especially for employed women. For example, "in Denmark, at least 75 percent of childcare costs are covered by the municipality. At a maximum of 138 euro per month for the first child and less for additional children, childcare costs in Sweden are also comparatively low. From the age of three, children also have the right to 525 hours of care free of charge per year. In Finland, the maximum contributions per child are 254 euro per month and considerably lower for siblings. French and Swiss preschool is funded entirely by the public purse." 17

Although a correlation between poor childcare infrastructure and lack of work-life balance has not been established, there is still a need for public childcare policies in order to offer employed women almost the same opportunities as men.

\footnotetext{
${ }^{13}$ Mercader Uguina, Jesús R. (2013). Lecciones de derecho del Trabajo, Tirant lo blanch, Valencia, p. 434.

${ }^{14}$ Judgements by regional Higher Courts of Justice (STSJ in Spanish). STSJ of Madrid May 16, rec. 2946/2011, FJ Único; STSJ de la Comunidade Valenciana November, rec. 845/2010, FJ 1.4; STSJ Andalucía, July 19, rec. 325/2009, FJ $2^{\circ}$.

${ }^{15}$ Jover Ramírez, Carmen (2013). "La difícil supervivencia de la conciliación entre la vida laboral y familiar en tiempos de crisis y reforma”, Revista Doctrinal Aranzadi Social, no. 4/2013 parte Doctrina.

${ }^{16}$ Hennig, M., Stuth, S., Евach, M. \& HägGlund, A.E. (2012). "How do employed women perceive the reconciliation of work and family life? A seven-country comparison of the impact of family policies on women's employment", International journal of sociology and social policy, vol. 32, no. 9-10, pp. 513-529.

${ }^{17}$ Hennig, M., Stuth, S., Ebach, M. \& HäGglund, A.E. (2012), op.cit., page 12.
} 


\section{B. Part-Time Contract (art. 12 of the Workers' Statute)}

A part-time contract is defined as an agreement to provide services during a number of hours per day, week or year, inferior to a full-time comparable employee (art. $12 \mathrm{WS}$ ). From the definition found in the Workers' Statute, part-time contracts are not merely a reduction of working hours (full-time contract with reduction of working hours) or a reduced utilization of working hours, since they are contracts having a complex legal configuration, formal requirements and the possibility of changing from full-time to part-time and vice versa.

Article 12 WS defines a comparable full-time employee as the one that: i) works in the same enterprise, ii) with the same labour contract; and iii) who works in the same or similar job.

Nevertheless, in order to consider a contractual relationship as part-time, it is not enough to work fewer hours than a full-time employee. Indeed, the reduction of working hours must be voluntarily adopted by the employee and is subject to a part-time contract, as stated in art. 12.4c) WS and jurisprudence of the Spanish Supreme Court (SC) ${ }^{18}$. The lack of wilfulness means that neither the suspension of the contract due to economic, technical, organizational or production reasons or force majeure, nor the reduction of working hours due to guardianship or the care of family members are considered to be part-time contracts ${ }^{19}$.

Regarding the same, Germany is, perhaps, the most generous country, given that "employees of companies with a minimum of 15 employees and who have at least six months length of service have the right to part-time employment; however they do not have any right to change back from part-time work to full-time. A company may only refuse a request for part-time work for organisational reasons. In Great Britain, in contrast, the right to part-time work is limited to parents of children up to 16 years. [...] In France, where 23 percent of employed women work part-time, following the birth of a child, employees have the right to reduce their working hours to up to 16 hours up to the child's third birthday. Almost one-fifth of women in Denmark work for fewer than 30 hours per week [...]. However, there is no legal right to part-time work in Denmark. There is no universal right to part-time in Sweden either: 16 percent of employed women there work less than 30 hours per week. However, parents have a right to work part-time until their child is eight year old. They can reduce their working hours up to 75 percent." ${ }^{20}$ In Spain, part-time work is not a right but a contractual option for the employee.

Part-time contracts have suffered the most modifications since the enactment of the Workers' Statute in 1980. All of the reforms agree on the need to enhance this type of contract, since it is considered to be an appropriate mechanism to revitalize the Spanish labour market in terms of the distribution of work time. Therefore, it was surprising that the recovery of extraordinary hours was the only measure introduced in the most recent labour reform, conducted by Act 3/2012.

Nonetheless, the possibility of part-time employees working extraordinary hours was soon removed by Act 16/2013, which once again modified article 12 WS. Reflection is necessary as to why extraordinary hours tend to be an issue of conflict and why legislators have not considered the possibility of exchanging supplementary hours for extraordinary hours. The answer is quite simple: supplementary hours are paid as ordinary hours whereas, economically speaking, extraordinary hours are more expensive.

Since the modification introduced by Act 16/2013, the distribution of work hours would be stated in the collective negotiation agreement, instead of in the actual contract. Although this constitutes an improvement, the risk of the company's distributing employee working hours remains. The lack of a general regimen regarding this issue makes the part-time contract unattractive to workers who aim to balance work and family life.

Part-time workers have the same indivisible working rights as full-time workers, although the rights that can be measured are granted in proportion to number of hours worked (art. 12.4d WS and Supreme Court Judgement (STS) $15^{\text {th }}$ November of 2006, rec. 103/2005).

On the other hand, the distribution of supplementary hours is no longer included in either the

\footnotetext{
${ }^{18}$ Judgements of the Supreme Court: May 14 of 2007, rec. 85/2006 and October 7 of 2011, rec. 144/2011.

${ }^{19}$ Judgements of the Supreme Court, May 14 of 2007, rec. 85/2006.

${ }^{20}$ Hennig, M., Stuth, S., Eвach, M. \& HägGlund, A.E. (2012). "How do employed women perceive the reconciliation of work and family life? A seven-country comparison of the impact of family policies on women's employment", International journal of sociology and social policy, vol. 32, no. 9-10, pp. 523.
} 
collective negotiation or the specific agreement, as occurred prior to the last labour reform. As a result of this lack of regulation, part-time workers perceive this type of contract to be less suitable to balance their working and family life, since it is impossible for a worker to reconcile their labour and family life if they do not know when they will be required by their employer.

According to the goal of making part-time contracts more flexible, supplementary hours can be agreed upon and may be voluntary. Agreed supplementary hours are mandatory when the employee has signed the prescriptive agreement. On the other hand, the employer can only offer voluntary supplementary hours when part-time contracts are permanent in duration [art. 12.5a)-g) WS]. Furthermore, according to article $12.5 \mathrm{WS}$, the most recent draft, supplementary hours can only be completed by employees whose ordinary working time, as stated in their contract, is at least ten hours per week in annual figures. This last measure is clearly an incentive directed towards employees against the flexible measures introduced by Act 16/2013, which benefit employers.

The measures introduced by Act 16/2013 have made part-time contracts more flexible and attractive to employers as opposed to employees, who still perceive this figure as being unsuitable to the reconciliation of their labour and family life, preferring to reduce their working hours for guardianship or family care.

After exposing the Spanish regulation regarding part-time work, we shall now consider how the Spanish part-time work situation differs from those existing in countries such as the Netherlands, Germany and Sweden. How does part-time work help to accomplish the work-life balance in these countries?

According to the Organization for Economic Cooperation and Development (OECD) data, parttime work is prevalent in The Netherlands. "Dutch employees are legally protected and can adjust their working hours in their current job" whereas "Germany, [...] and Sweden are useful benchmarks because they represent typical conservative, [...] and Nordic regimes and are characterized by varying levels of part-time work prevalence and protection". ${ }^{21}$

Before detailing the merits of part-time work regulation in these countries, it is necessary to describe what exactly part-time work is considered to be. The OECD establishes a threshold of approximately 30 hours a week ${ }^{22}$, while the Dutch statistical institute (SCP and CBS) establishes it between 12 and 34 hours per week. In fact, if the threshold is set between 12 and 19 hours a week, it is informally referred as a "small part-time job", whereas a "large part-time job" consists of between 20 and 34 hours per week ${ }^{23}$.

Collective negotiation and the right to adopt work hours constitute the key to success in these European countries. In both the Netherlands and Sweden, "employee representatives are strongly involved in developing employment policies [...]. For example, in the Netherlands, protective provisions for parttime employees are included in collective negotiation agreements since the early 1990s. In contrast, German employer organizations continue to resist legislation governing part-time work". ${ }^{24}$

"The ILO considers the employees' ability to adapt their hours to their needs as a requirement of decent work. [...] the Netherlands has designed what is probably the most comprehensive state effort to increase high quality part-time work. The Wet aanpassing arbeidsduur (Working Hours Adjustment Act), enacted in 2000, allows employees to request variable working hours. Employers may only reject this request if they can prove it would seriously harm the organization. The content and roots of Swedish legislation are similar to those of Dutch legislation. Swedish employees have the right to adjust their working hours, which provide large opportunities for households to adapt their working time to various situations and commitments over the life course without significant income losses. In the early 2000s, Germany introduced legislation that increased access to part-time work and made it possible to adjust one's working hours. However, the scope and impact in German legislation are more limited, and parttimework has not reached the same normalized status as in the Netherlands". ${ }^{25}$

\footnotetext{
${ }^{21}$ Roeters AnNe and Lyn Craig. 2014, "Part-time work, women's work-life conflict, and job satisfaction: A cross-national comparison of Australia, the Netherlands, Germany, Sweden, and the United Kingdom”, International journal of sociology and social policy, vol. 53, no. 9-10, pp. 185-213.

$22 \mathrm{http}: / /$ stats.oecd.org/

${ }^{23}$ http://www.cbs.nl/en-GB/menu/_unique/_concept/ default.htm?postingguid=\{C5053425-F9AF-4CE2-96EC-30FA4D5BA0A6 $\&$ concept $=$ Part-time + jobs 9

${ }^{24}$ Roeters Anne and Lyn Craig. 2014, op. cit. page 13.

${ }^{25}$ Roeters Anne and Lyn Craig. 2014, op. cit. page 13.
} 
As revealed in this study, Spanish workers do not have the right to adjust working hours to their needs. Although Act 16/2013 enables collective negotiation to determine the distribution of working time, an advance on this matter since employee representatives can exert more pressure; Spanish workers are still far from achieving the situation enjoyed by Dutch and Swedish workers. In fact, as we shall expose in the next section, although the adaptation of working hours is a legal right (Art. $34.8 \mathrm{WS}$ ), the requirement of a collective or individual negotiation precludes the application of that right.

\section{Adaptation of length and distribution of working time as a legal right to reconcile working and family life (art. 34.8 of the Workers' Statute)}

After the study of the reduction of working hours for legal guardianship or for care of family members and the part-time contract, the issue of what happens in the other cases that are not specifically contemplated by the law, inevitably arises. For example, a shift worker who requests a permanent shift due to the lack of a legal provision regarding the right to switch shifts under guardianships circumstances. Another example is the employee with family responsibilities, differing from those described in art. $37 \mathrm{WS}$, requesting a change from his/her full-time contract to a part-time one, but the request is declined due to the lack of vacancy and the organizational necessities.

Issues such as these, which are not contemplated in the WS, tend to generate conflict in the Courts, since most employees under these circumstances appeal to art. $34.8 \mathrm{WS}$, on behalf of which the employee has the right to adapt the length and distribution of his working time in order to reconcile his/her working and family life. This right extends beyond that stated in art.37.5 and 6 WS since a proportionate salary reduction is not contemplated and it gives the possibility to change the working shift. Nonetheless, art. 34.8 WS makes this right conditional on the existence of a collective or individual agreement on the matter.

Act 3/2012 has modified art. 34.8 WS by introducing a new paragraph, which simply states that it will "promote" the reconciliation between the right to work-life balance and the improvement of productivity in the company environment. This novelty is ineffective since the right to reconcile work and family life still depends on the existence of a collective or individual agreement. Once again, legislation has failed to expressively determine the parties obliged to reach an agreement on this matter and to establish the consequences of failing to reach an agreement.

This legal alternative is not free of criticism at the very heart of the doctrine ${ }^{26}$, since it is considered to be insufficient in comparison with other measures, such as in the case of gender related violence (art. 37.7 WS), where the legislative solution has further widened in defect of a collective or individual agreement, the very female employee has the right to determine the length and distribution of her working hours with the single limit of respecting the rules established in art. $37.6 \mathrm{WS}$.

Constitutional jurisprudence makes it clear that interpretation discrepancy exists not only in the ordinary Courts but also at the Supreme Court level, in the interpretation of the legal rights to reconcile work and family life, the right to not be discriminated against (art. 14CE) and the right to protect the family, understood as a jurisdictional asset (rt. 39).Nevertheless, since 2007, the Constitutional Court has agreed on the need for ordinary jurisdiction bodies to consider the constitutional dimension of art. $34.8 \mathrm{WS}^{27}$.

Other than the constitutional doctrine established in 2007 regarding art. $34.8 \mathrm{WS}$, its effectiveness has been almost non-existent, especially in the shift working regime, claiming the impossibility to apply paragraphs 5 and 6 of art. $37 \mathrm{WS}$ and failing to recognize a switch of shifts as part of the right to reconcile working and family life, in addition, to the necessity of a collective or individual agreement. ${ }^{28}$

\footnotetext{
${ }^{26}$ Sánchez Urán Azaña, Yolanda (2012). "Adaptación de la jornada laboral por circunstancias familiares: la familia como bien jurídico protegido (reflexiones en torno a la STC 24/2011)", Civitas Revista española de Derecho del Trabajo, no. $155 / 2012$, pp. 282-283.

${ }^{27}$ Judgement of the Constitutional Court, January 15 of 2007, rtc 2007/3; Judgement of the Constitutional Court, March 14 of 2011, rtc 2011/24 ; and Judgement of the Constitutional Court, March 14 of 2011, rtc 2011/26

${ }^{28}$ CAstelli, Nunzia (2012). "Conciliación de la vida familiar y laboral y exigencias organizativas empresariales", Revista Doctrinal Aranzadi Social, no. 2/2012 paragraph 1/2012.
} 


\section{Spanish Part-Time Work Data}

Female incorporation in the labour market has brought into debate not only the need to enable employees to reconcile their working and family life, but also the necessity to redefine male-female roles in society. Women demand the same labour opportunities as men, and this requires a change of culture in all spheres of society.

In order to determine whether any change has occurred with regards to the issue of gender equality in the sphere of reconciliation, this study uses data from the Economically Active Population Survey (EPA in Spanish) to show the reasons why workers choose part-time work and its distribution over the past 10 years $^{29}$.

\section{Chart 1}

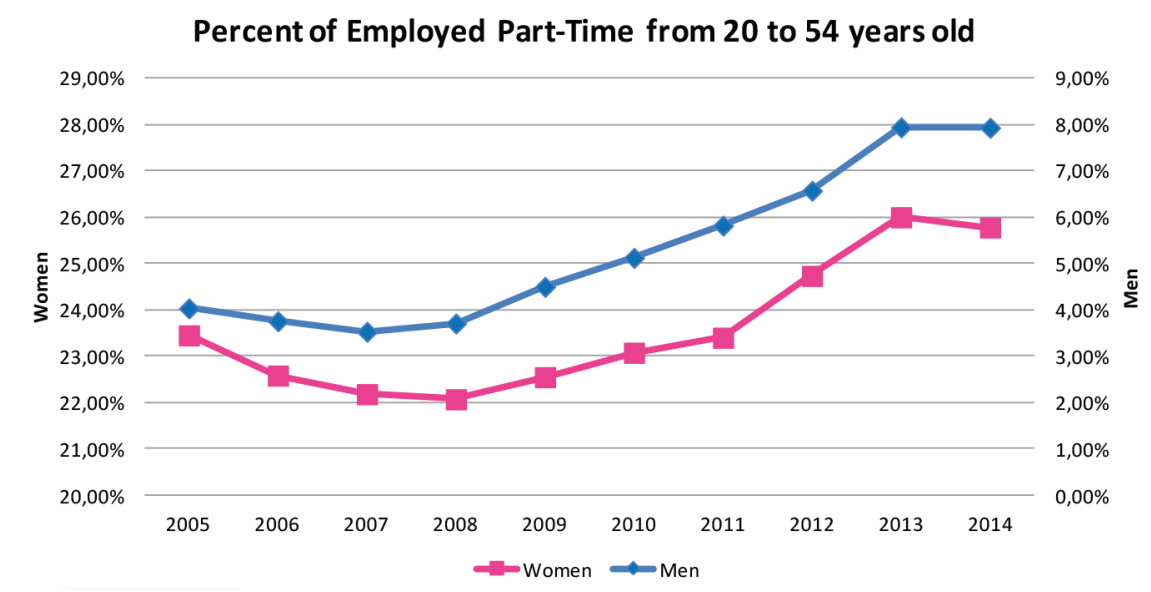

Source: The graph was made using data from The Spanish National Statistical Institute (www.ine.es)

This graph reveals that even though part-time employment has had a proportionately higher increase in male workers, it is still predominantly conducted by female workers.

The following two graphs show the reasons why workers choose part-time work.

\section{Chart 2: Women}

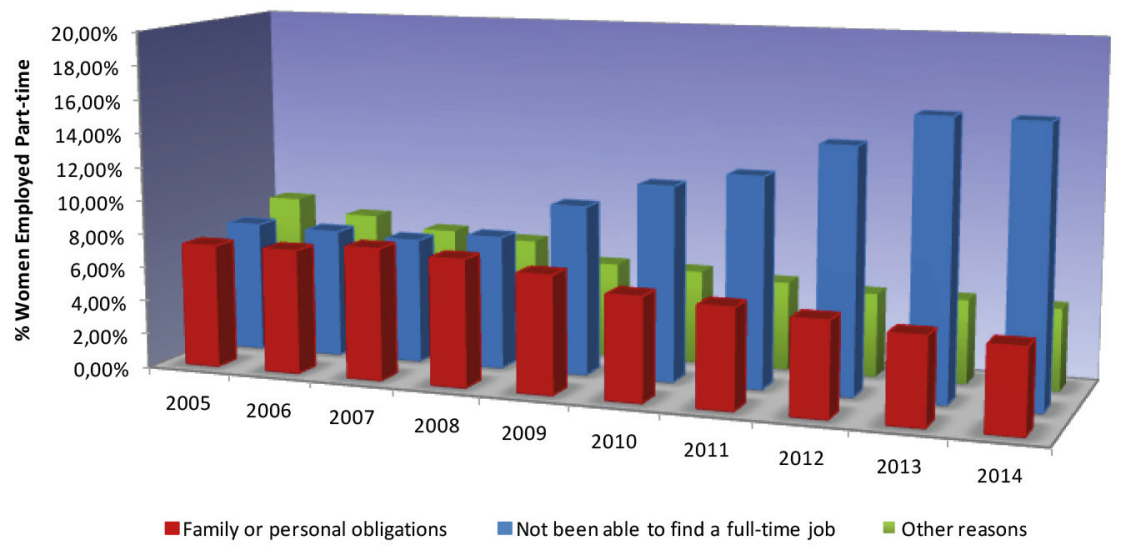

Source: The graph was made using data from the Spanish National Statistical Institute (www.ine.es)

${ }^{29} \mathrm{http}: / /$ www.ine.es/dyngs/INEbase/en/operacion.htm?c=Estadistica_C\&cid=1254736176918\&menu=ultiDatos\&idp=12547 35976595 


\section{Chart 3: Men}

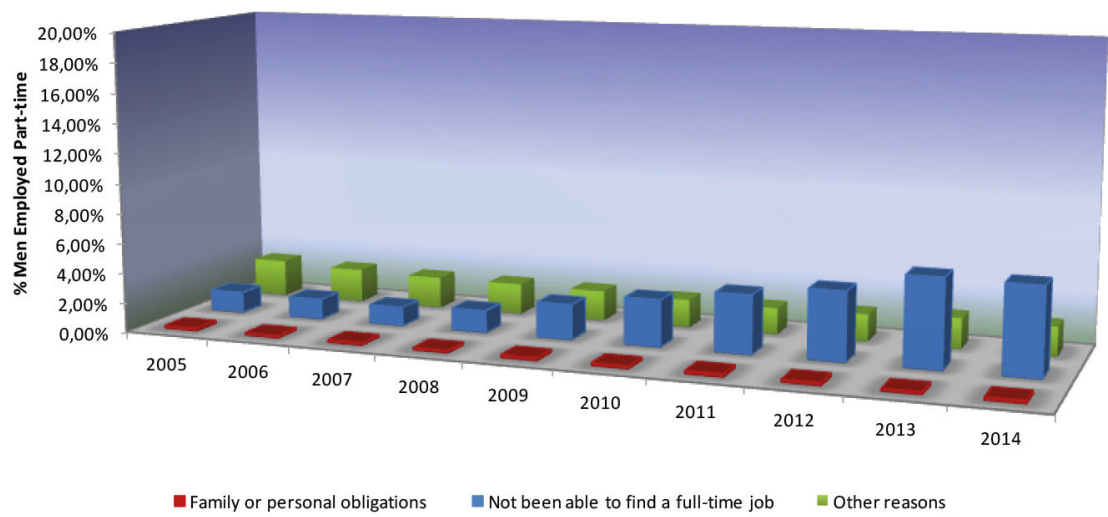

Source: The graph was made using data from the Spanish National Statistical Institute (www.ine.es),

We can see that during the economic crisis, "family responsibilities" as a cause moved into second place for female workers, with "not been able to find a full-time job" being the first reason for holding a part-time job. In 2011, 12.3\% of women held a part-time job for the reason of "not been able to find a full-time job", while $11 \%$ of them had a part-time job for other reasons. In 2013 , the difference becomes greater, $16 \%$ against $10 \%$.

On the other hand, male workers with a part-time job are a minority, and "not been able to find a full-time job" was the main reason for that. The weight of "Family responsibilities" in male workers for choosing a part-time job is almost insignificant, as seen in chart 3.

This prevalence of part-time work in females is not only common in Spain, but also across many countries. According to a study by Roeters and Craig: "part-time work is much more prevalent among women than it is among men. Although attitudes vary across countries, it is widely considered harmful to young children if their mother works full-time, especially when high-quality childcare is unavailable. Women anticipate future family responsibilities by choosing jobs with fewer hours, even before they actually have children. Part-time employment among men is low (in 2006, male part-time rates varied between $9.9 \%$ in Germany and $27.2 \%$ in the Netherlands, OECD, 2014), and although it is not frequently studied, it appears that men chose to work part-time for different reasons than women. In the Netherlands, for example, the presence of children has only a minor impact on men's working hours. ${ }^{\prime 30}$

\section{Conclusions}

Spanish employees have to turn to different institutional figures in order to reconcile their working and family life, due to the lack of flexibility that the general law provides in this matter. Furthermore, Spanish employees having family responsibilities are less protected by its government than Dutch, Swedish or German workers, who enjoy public aid that is offered in different manners, from economical subsidies to public assistance and facilities.

A change of culture is needed soon, not only from the Spanish government but also from social partners, who have shown their inability to turn the prominence given to collective negotiation into an opportunity to improve the situation of employees having family responsibilities while responding to the productivity claim of the corporate sphere.

\footnotetext{
${ }^{30}$ Roeters AnNe and Lyn Craig 2014, "Part-time work, women's work-life conflict, and job satisfaction: A cross-national comparison of Australia, the Netherlands, Germany, Sweden, and the United Kingdom", International journal of sociology and social policy, vol. 53, no. 9-10, pp. 185-213.
} 
Data suggests a lack of change in terms of equality regarding the reconciliation of working and family life. Firstly, part-time jobs continue to be prevalent among women, despite countercyclical behaviour among men. Secondly, although the economic crisis has led to "family responsibilities" being considered the second-ranked priority among female workers, the difference between women and men have not changed. Finally, the rates of men having a part-time job for family reasons have not varied.

The issue of reconciling working and family life requires additional attention, not only from national institutions but also from international ones, since the western world is experiencing population aging and a change of its pyramid, which is becoming increasingly narrower due to a decrease of the youth. Women continue to postpone maternity; therefore it is urgent to adopt measures that permit them to have the same labour opportunities as men, not forcing them choose between a professional career and a family. This may be accomplished by increasing awareness of the need to share family responsibilities.

\section{References}

Aguilera Izquierdo, Raquel. (2007). "Los derechos de conciliación de la vida personal, familiar y laboral en la Ley Orgánica para la igualdad efectiva de mujeres y hombres, Revista del Ministerio de Trabajo y Asuntos Sociales, no. Extra, pp. 69-119.

Alarcón CARACUel, Manuel RAmón. (2011). "La jornada ordinaria de trabajo y su distribución", in Tiempo de Trabajo, (Coordinators: Aparicio Tovar, Joaquín and Juan López Gandía), Editorial Bomarzo, pp. 33-55.

Álvarez Llorente, Gema. (Third Quarter 2004 and First Quarter 2005). “Análisis empírico de los determinantes de la satisfacción laboral en España”, Revista de Economía y Empresa, no. 52 and 53, pp. 105-118.

Ballester Pastor, María Amparo. (2010). "Conciliación laboral y familiar en la Unión Europea: rémoras, avances y nuevas líneas de tendencia en el ámbito de la corresponsabilidad", Revista de Derecho Social, no. 51, pp. 31-66.

Ballester Pastor, María Amparo. (2013). "La flexibilidad en la gestión del tiempo de trabajo: jornada y distribución del tiempo de trabajo", Revista de Derecho Social, no. 62, pp. 53-92.

Blázquez Cuesta, Maite and Nuria Elena Ramos Martín. (2009). "Part-time employment: a comparative analysis of Spain and the Netherlands", European Journal of Law and Economics, vol. 28, pp. 223-256.

Cabeza Pereiro, Jaime. (2013). El trabajo a tiempo parcial y las debilidades del modelo español, Editorial Bomarzo.

Cabeza Pereiro, Jaime and Belén Fernández Docampo. (2012). "Reducción de la jornada por el «Ordeno y mando»", Revista de Derecho Social, no. 58, pp. 171-192.

Cano Galán, Yolanda. (2011). "Tiempo de trabajo y conciliación de la vida familiar y laboral en la negociación colectiva”, in Horarios y sociedad: una visión multidisciplinar, (Bellón Sánchez de la Blanca, Teresa [et al.]), Dykinson, Colección Ciencias jurídicas y sociales, 135, pp. 103-132.

CAstelli, Nunzia. (2012). "Conciliación de la vida familiar y laboral y exigencias organizativas empresariales”, Revista Doctrinal Aranzadi Social, no. 2/2012 para. 1/2012.

Connolly, Sara and Mary Gregory. (2010). "Dual tracks: Part-time work in life-cycle employment for Bristish women”, Journal of Population Economics, 23 (3), pp. 907-931.

Crompton, R. \& Lyonette, C. 2006, “Work-Life 'Balance' in Europe”, Acta Sociologica, vol. 49, no. 4, pp. 379-393.

Cruz Villalón, Jesús. (2013). Compendio de Derecho del Trabajo, Tecnos, Madrid.

Fraguas Madurga, Lourdes. (2013). "Reducción de jornada y flexibilidad horaria por cuidado de hijos tras la reforma laboral de 2012", Revista Doctrinal Aranzadi Social, no. 10/2013.

García-Perrote Escartín, Ignacio. (2012). "Medidas para favorecer la flexibilidad interna en las empresas en la Ley 3/2012, de 6 de julio, de medidas urgentes para la reforma laboral", in La Regulación del Mercado Laboral: Un análisis de la Ley 3/2012 y de los aspectos laborales del Real 
Decreto-Ley 20/2012, (Directors: Mercader Uguina, Jesús and Ignacio García-Perrote Escartín), Lex Nova, Valladolid, pp. 263-281.

Gil Plana, Juan. (2012). "La STC núm. 26/2011, de 14 de marzo, relativa al derecho del progenitor a conciliar la vida laboral y el cuidado de hijos menores y la configuración de esta circunstancia personal como factor discriminatorio", Civitas Revista española de Derecho del Trabajo, no. 154/2012, 261-284.

Gimeno díaz de Atauri, Pablo. (2012). "La recuperación de las horas extraordinarias en el trabajo a tiempo parcial", in La Regulación del Mercado Laboral: Un análisis de la Ley 3/2012 y de los aspectos laborales del Real Decreto-Ley 20/2012, (Directors: Mercader Uguina, Jesús and Ignacio García-Perrote Escartín), Lex Nova, Valladolid, pp.115-134.

Grau-Grau, M. 2013, "Clouds over Spain: work and family in the age of austerity", International journal of sociology and social policy, vol. 33, no. 9-10, pp. 579-593.

Gregory, A., Milner, S. \& Windebank, J. 2013, "Work-life balance in times of economic crisis and austerity", International journal of sociology and social policy, vol. 33, no. 9-10, pp. 528-541

HANTRAIS, L. \& AcKers, P. 2005, "Women's choices in Europe: striking the work-life balance", European journal of industrial relations, vol. 11, no. 2, pp. 197-212.

Hennig, M., Stuth, S., Ebach, M. \& Hägglund, A.E. 2012, "How do employed women perceive the reconciliation of work and family life? A seven-country comparison of the impact of family policies on women's employment", International journal of sociology and social policy, vol. 32, no. 9-10, pp. 513-529.

Herraiz Martín, Ma Sol. (2012). "La conciliación de la vida laboral y familiar en la Ley 3/2012: Luces y sombras", in La Regulación del Mercado Laboral: Un análisis de la Ley 3/2012 y de los aspectos laborales del Real Decreto-Ley 20/2012, (Directors: Mercader Uguina, Jesús and Ignacio García-Perrote Escartín), Lex Nova, Valladolid, pp. 317-340.

Instituto Nacional de Estadística. (2012-2013). "Mujeres y Hombres en España”, Catálogo de publicaciones de la Administración General del Estado, available on http://publicaciones oficiales. boe.es and on the INE's site, www.ine.es.

Jover Ramírez, CARmen. (2013). "La difícil supervivencia de la conciliación entre la vida laboral y familiar en tiempos de crisis y reforma", Revista Doctrinal Aranzadi Social, no. 4/2013 parte Doctrina.

LaCASA, José María. (2013). "La reforma laboral desde el punto de vista empresarial”, Boletín de estudios económicos, no. 209, pp. 191-204.

Lahera Forteza, Jesús and Juan Carlos García QuiÑones. (2009). Tiempo de trabajo y conciliación familiar, Editorial Bomarzo.

LÓPEZ GANDÍA, JuAN. (2013). "Trabajo a tiempo parcial y valor de las cotizaciones según la reciente jurisprudencia del Tribunal Constitucional. (comentario a la STC 61/2013, de14 de marzo)", Revista de Derecho Social, no.61, pp. 135-150.

LÓPEZ GANDíA, JuAn. (2011). "La jornada reducida tras la ley de igualdad (aspectos laborales)”, in Tiempo de Trabajo, (Coordinators: Aparicio Tovar, Joaquín and Juan López Gandía), Editorial Bomarzo, pp. 143-173.

Lorenzo Rodríguez-Armas, Magdalena. (2004). "La conciliación de la vida familiar y laboral en serio: apuntes constitucionales para una conciliación acorde con la igualdad y el principio de no discriminación por razón de sexo", Anuario Jurídico y Económico Escurialense, XXXVII, pp. 76-93.

Maldonado Montoya, Juan Pablo. (2011). "Hacia la flexibilidad del tiempo de trabajo", in Horarios y sociedad: una visión multidisciplinar, (Bellón Sánchez de la Blanca, Teresa [et al.]), Editorial Dykinson, Colección Ciencias jurídicas y sociales, 135, pp. 63-78.

Martín Flórez, LouRdes. (2013). "Concreción de horario derivada de reducción de jornada por cuidado de hijos", Revista Doctrinal Aranzadi Social, no. 7/2013 para. 1/2013.

Martín-Llaguno, Marta and Cristina Guirao-Mirón. (2013). "El marco jurídico de la conciliación. Revisión de las políticas de conciliación en España desde 1999 hasta 2009”, Portularia, Vol. XIII, no. 1, 1-9. 
Meil, Gerardo and Cristina García Sainz [et al.]. (2007). El desafio de la conciliación de la vida privada y laboral en las grandes empresas, Fundación General de la Universidad Autónoma de Madrid.

Mercader Uguina, Jesús R. (2013). Lecciones de Derecho del Trabajo, Tirant lo blanch, Valencia.

Moreno Colom, Sara. (2010). "El tiempo de trabajo: de la jaula dorada a la libertad azarosa", Cuadernos de Relaciones Laborales, Vol. 28, no. 2, 299-321.

Moreno VidA, Ma NiEves. (2012). "Novedades en materia de modalidades contractuales: contrato indefinido para pequeñas empresas, trabajo a tiempo parcial y trabajo a distancia", Temas LaboralesRevista andaluza de trabajo y bienestar social, no. 115/2012, pp. 193-219.

Ortega Prieto, Eduardo and Eduardo Ortega Figueiral. (2012). La Reforma Laboral 2012, La Ley CISS, Madrid.

Quintanilla Navarro, Beatriz. (2005). "La conciliación de la vida laboral y familiar en el marco jurídico actual", Cuadernos de Relaciones Laborales, Vol. 23, no.1, pp. 95-129.

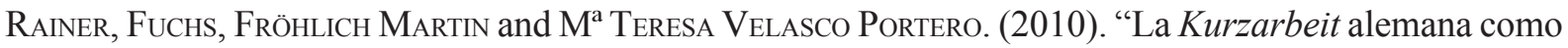
modelo para la reducción temporal de jornada en España", Dereito, Vol. 19, no. 2, pp. 347-370.

Ramos Quintana, Margarita Isabel. (2014). "Tiempo de trabajo y conciliación de vida personal, familiar y laboral: Riesgos psicosociales emergentes", in Salud en el trabajo y riesgos laborales emergentes, (Coordinator: Grau Pineda, $\mathrm{M}^{\mathrm{a}}$ del Carmen) Editorial Bomarzo, pp. 89-111.

Rico Belda, Paz. (2012). "Satisfacción con la conciliación laboral y familiar de los asalariados en España”, Revista de Economía Laboral, no. 9, pp. 30-45.

SÁnchez-URÁn Azaña, Yolanda. (2012). "Adaptación de la jornada laboral por circunstancias familiares: la familia como bien jurídico protegido (reflexiones en torno a la STC 24/2011)", Civitas Revista española de Derecho del Trabajo, no. 155/2012, pp. 271-289.

Roeters Anne and Lyn Craig. 2014, "Part-time work, women's work-life conflict, and job satisfaction: A cross-national comparison of Australia, the Netherlands, Germany, Sweden, and the United Kingdom”, International journal of sociology and social policy, vol. 53, no. 9-10, pp. 185-2013.

SÜSS, S. \& SAYAH, S. 2013, "Balance between work and life: a qualitative study of German contract workers", European management journal, vol. 31, no. 3, pp. 250-262.

ThÉvenon, O. 2009, “Increased Women's Labour Force Participation in Europe: Progress in the WorkLife Balance or Polarization of Behaviours?", Population, vol. 64, no. 2, pp. 235-272.

Torns Martín, Teresa. (2005). "De la imposible conciliación a los permanentes malos arreglos", Cuadernos de Relaciones Laborales, Vol. 23, no. 1, 15-33.

Ubillús Bracamonte, Rolando E. (2013). "La concreción horaria y la reducción de la jornada por cuidado de hijo menor", Revista Doctrinal Aranzadi Social, no. 21/2013 para. 3/2013.

Valdés Dal-Ré, Fernando. (2013). "La reforma de 2012 (Nota sobre su texto- sistemática interna y calidad técnica- y su contexto -la falta de correspondencia entre el objetivo proclamado y los objetivos realmente perseguidos-)", Relaciones Laborales, no. 2, pp. 1-10.

VAn, D.L., JAGER, A. \& KoPS, Y. 2006, "Combination Pressure. The Paid Work-Family Balance of Men and Women in European Countries", Acta Sociologica, vol. 49, no. 3, pp. 303-319.

VilaPLANA, CRISTINA. (2010). "Conciliación entre vida laboral y cuidados informales a personas mayores dependientes en España", Revista de Economía Laboral, no. 7, pp. 82-125.

Wattis, L., Standing, K. \& Yerkes, M.A. 2013, "Mothers and work-life balance: exploring the contradictions and complexities involved in work-family negotiation", Community, work and family, vol. 16, no. 1, pp. 1-19. 